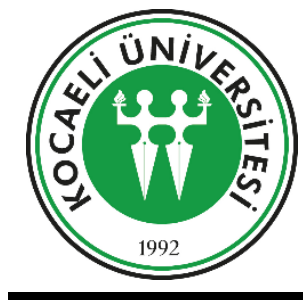

Kocaeli Üniversitesi Sağlık Bilimleri Dergisi

Özgün Araştırma / Original Article

http://dergipark.gov.tr/kusbed

\title{
EVALUATION OF CORNEAL LANGERHANS CELLS IN PATIENTS WITH THYROID OPHTHALMOPATHY BY USING AN IN VIVO CONFOCAL MICROSCOPY: A RETROSPECTIVE STUDY
}

\author{
TIROID OFTALMOPATİ HASTALARINDA IN VIVO KONFOKAL MIKROSKOPI KULLANILARAK \\ LANGERHANS HÜCRELERININ DEĞERLENDIRILMESI: RETROSPEKTIF BIR ÇALIŞMA
}

Büşra Yılmaz Tuğan ${ }^{1 *}$

${ }^{1}$ Kocaeli University, Medical School, Department of Ophthalmology, Kocaeli, Turkey

ORCID iD: Büşra Yılmaz Tuğan: 0000-0001-6660-1608

*Sorumlu Yazar / Corresponding Author: Büşra Yılmaz Tuğan, e-posta / e-mail: busrayilmaz87@ hotmail.com

Geliş Tarihi / Received: 13.04 .2021

Kabul Tarihi / Accepted: 05.05.2021

Yayım Tarihi / Published: 29.05 .2021

\begin{abstract}
Objective: To assess corneal Langerhans cell (LC) density in thyroid-associated ophthalmopathy (TAO) patients to evaluate the role of inflammation in ocular surface disease related to TAO by using in vivo confocal microscopy (IVCM).

Methods: Thirty-three patients who had inactive disease [(Clinical Activity Score $(\mathrm{CAS})<3$ ] and thirty age-matched healthy control subjects were enrolled in the study. All subjects underwent routine ophthalmologic examination including visual acuity levels, intraocular pressure, anterior segment, and posterior segment evaluation. The subjects were evaluated with tear break-up time (BUT). IVCM was performed to assess LC density in the central cornea. Also, correlation analyses of LC density and clinical data were performed.

Results: The mean BUT was $9.61 \pm 5.01$ seconds in the TAO group and $12.70 \pm 2.76$ seconds in the control group ( $p=0.003$ ). The median central corneal LC density in the control group was 19.00 (7.00-24.50) whereas it was significantly increased to $68.00(50.00-92.00)$ in the TAO patients $(p<0.001)$. In correlation analysis, there was a significant negative correlation between age and CAS of TAO patients $(r=-0.348, p=0.047)$, and the age of TAO patients was not correlated with BUT and LC count ( $r=0.236, p=0.186$ and $r=-0.211, p=0.240$, respectively). BUT of TAO patients was negatively correlated with LC count and CAS ( $r=-0.495, p=0.003$ and $r=-0.644, p<0.001$, respectively). The CAS of the patients was not correlated with the LC count of the patients $(r=0.261, p=0.143)$. In the control group, BUT, CAS and LC count was not correlated with each other.

Conclusion: TAO patients in the inactive phase suffer from ocular surface inflammation and LC participates in corneal inflammation in TAO.
\end{abstract}

Keywords: Langerhans cells, in vivo confocal microscopy, ocular surface, thyroid-associated ophthalmopathy

$\ddot{O} z$

Amaç: Tiroid orbitopati (TAO) hastalarında görülen oküler yüzey hastalığında inflamasyonun rolünün in vivo konfokal mikroskopi (IVKM) ile korneal Langerhans hücre (LH) yoğunluğu araştırılarak değerlendirilmesi.

Yöntem: Otuz üç inaktif hasta [(Klinik Aktivite Skoru $(\mathrm{KAS})<3]$ ve otuz yaş uyumlu sağlıklı kontrol çalışmaya alındı. Tüm katılımcılara görme keskinliği seviyesi, göz içi basıncı, ön ve arka segment muayenesini içeren rutin oftalmik muayene yapıldı. Ayrıca gözyaşı kırılma zamanı (GKZ) da değerlendirildi. Santral korneada LH yoğunluğu IVKM ile değerlendirildi. Ayrıca, konfokal mikroskopi bulguları ile klinik verilerin korrelasyon analizi yapıldı.

Bulgular: TAO grubunda ortalama GKZ 9,61 $\pm 5,01$ saniye, kontrol grubunda ise $12,70 \pm 2,76$ saniye idi ( $p=0,003$ ). Kontrol grubunda ortanca santral korneal LC yoğunluğu 19,00 (7,00-24,50) olmasına karşı TAO grubunda 68,00 (50,00-92,00)'e yükseldi $(p<0,001)$. Korrelasyon analizinde TAO hastalarında yaş ve KAS arasında anlamlı negatif korrelasyon görüldü $(r=-0,348, p=0,047)$ ve TAO hastalarının yaşı, GKZ ve LH sayısı ile korrele değildi (sırasıyla $r=0,236, p=0,186$ ve $r=-0,211, p=0,240$ ). TAO hastalarının GKZ değerleri LH sayısı ve KAS ile negatif korreleydi (sırasıyla $r=-0,495, p=0,003$ ve $r=-0,644, p<0,001)$. Hastaların KAS ile LH sayıs1 korrelasyon göstermedi $(r=0,261, p=0,143)$. Kontrol grubunda GKZ, KAS, LH sayısı birbiriyle korrele değildi.

Sonuç: İnaktif fazdaki TAO hastalarında oküler yüzey inflamasyonu görülür ve LH, TAO hastalarında görülen korneal inflamasyonda görev alır.

Anahtar Kelimeler: Langerhans hücreleri, in vivo konfokal mikroskopi, oküler yüzey, tiroid iliş̧ili oftalmopati 


\section{Introduction}

Thyroid-associated ophthalmopathy (TAO), also known as Graves' ophthalmopathy (GO) or thyroid eye disease is the most common autoimmune inflammatory orbital disease in adults. ${ }^{1}$

Clinical manifestations of TAO involve not only orbital connective tissue but also eyelid, lacrimal system, conjunctiva, and cornea. ${ }^{1}$ Ocular surface damage is frequent in TAO, but the etiology of the damage is unknown. Mechanical factors such as proptosis, incomplete blinking, lagophthalmos, and increased palpebral fissure width in TAO may lead to increased tear evaporation and ocular surface damage. ${ }^{2-4}$ A recent study revealed impaired cytokine balance in tear analysis of TAO patients. ${ }^{5}$ Gurdal et al. suggested that ocular surface inflammation could be the only presenting clinical manifestation before the presentation of classical TAO findings. ${ }^{6}$ Decreased aqueous production $^{7}$, increased tear evaporation and also inflammation play significant roles in ocular surface injury in TAO. ${ }^{6,8}$

Langerhans cells (LCs), a type of dendritic cells, act as the highly potent antigen-presenting cells located in the epithelial layer and initiate inflammatory responses on the ocular surface. ${ }^{9,10}$ Antigens can be captured, processed, and presented by LCs. Corneal LCs regulate and induce corneal immune process and normally they are localized both centrally and peripherally in the corneal epithelium. ${ }^{10,11}$

Confocal microscopy has recently been used to acquire coronal optical portions of the cornea as well as data on specific cell subtypes. Studies demonstrated density and distribution of LCs in healthy corneal epithelium, ${ }^{11}$ in pathological conditions like postoperative endophthalmitis, ${ }^{12}$ keratoconus, ${ }^{13}$ corneal trauma. ${ }^{14}$

In current research, we use in vivo confocal microscopy to investigate the density of corneal LCs in TAO patients in order to evaluate the role of inflammation in ocular surface disease related to TAO.

\section{Methods}

\section{Patients}

Thirty-three patients and thirty age-matched healthy control subjects were enrolled in the study. The mean age was $43.67 \pm 2.43$ in the TAO group and $42.30 \pm 2.27$ in the control group ( $p=0.197)$. The patients were assessed according to the Clinical Activity Score (CAS). ${ }^{15}$ Criteria for activity are spontaneous retrobulbar pain, pain on attempted up-gaze and downgaze, redness of eyelids, redness of conjunctiva, swelling of caruncle or plica, swelling of eyelids, swelling of conjunctiva (chemosis). The patients who had an inactive disease $(\mathrm{CAS}<3$ ) were enrolled in the study. The severity of the GO was assessed according to European Group on Graves' Orbitopathy. The patients with mild GO and moderate-to-severe GO were enrolled in the study. None of the patients had sight-threatening GO. The criteria for mild GO are; patients whose features of GO have only a minor impact on daily life insufficient to justify immunosuppressive or surgical treatment. They usually have one or more of the following: minor lid retraction $(<2 \mathrm{~mm})$, mild soft-tissue involvement, exophthalmos $<3 \mathrm{~mm}$ above normal for race and gender, no or intermittent diplopia and corneal exposure responsive to lubricants. The criteria for moderate-to-severe GO are; patients without sightthreatening GO whose eye disease has sufficient impact on daily life to justify the risks of immunosuppression (if active) or surgical intervention (if inactive). They usually have two or more of the following: lid retraction $\geq 2 \mathrm{~mm}$, moderate or severe soft-tissue involvement, or exophthalmos $\geq 3 \mathrm{~mm}$ above normal for race and gender, inconstant or constant diplopia.

Thyroid hormone function tests were normal. Exclusion criteria were: active GO, sight-threatening GO, ocular inflammatory diseases other than GO, rheumatologic diseases, surgery of the eye and periocular tissues in 6 months. The study numbered GOKAEK-2020/14.09 was approved by the Ethics Committee of KOU and followed the principles of the Declaration of Helsinki.

\section{Clinical Evaluation}

All patients were subjected to a routine ophthalmologic evaluation which included visual acuity levels, intraocular pressure, anterior segment, and posterior segment assessment. The patients were also evaluated with tear break-up time (BUT). The same researcher carried out all of the ophthalmic evaluations (B.YT).

\section{Confocal microscopy assessment}

The Heidelberg Retina Tomograph (HRT3) configured with a Rostock Corneal Module (RCM) (Heidelberg Engineering $\mathrm{GmbH}$, Heidelberg, Germany) was used to conduct in vivo confocal microscopy (IVCM) on the right eye of all participants. Topical anesthetic eye drops $(0.5 \%$ proxymetacaine hydrochloride, Alcaine ${ }^{\circledR}$; Alcon Laboratories, Fort Worth, TX) were used to anesthetize the ocular surface. The eye was aligned and fixated with the help of a mobile red-light target for the fellow eye. To maintain the distance between the cornea and the microscope head steady, a sterile packaging disposable plastic cap (Tomocap ${ }^{\circledR}$; Heidelberg Engineering GmBH, Almanya) was used. Carbomer gel (Viscotears $\AA$; Novartis, North Ryde, Australia) was used as a coupling medium between the applanating lens and the cornea. A digital camera tangential to the eye was used to track the positioning of the objective lens. The central region of each cornea was examined by in vivo confocal microscopy.

LCs were defined as bright corpuscular cells with or without dendrite-like indentations close around basal epithelial cells and the subbasal nerve plexus ${ }^{16}$ (Figure 1).

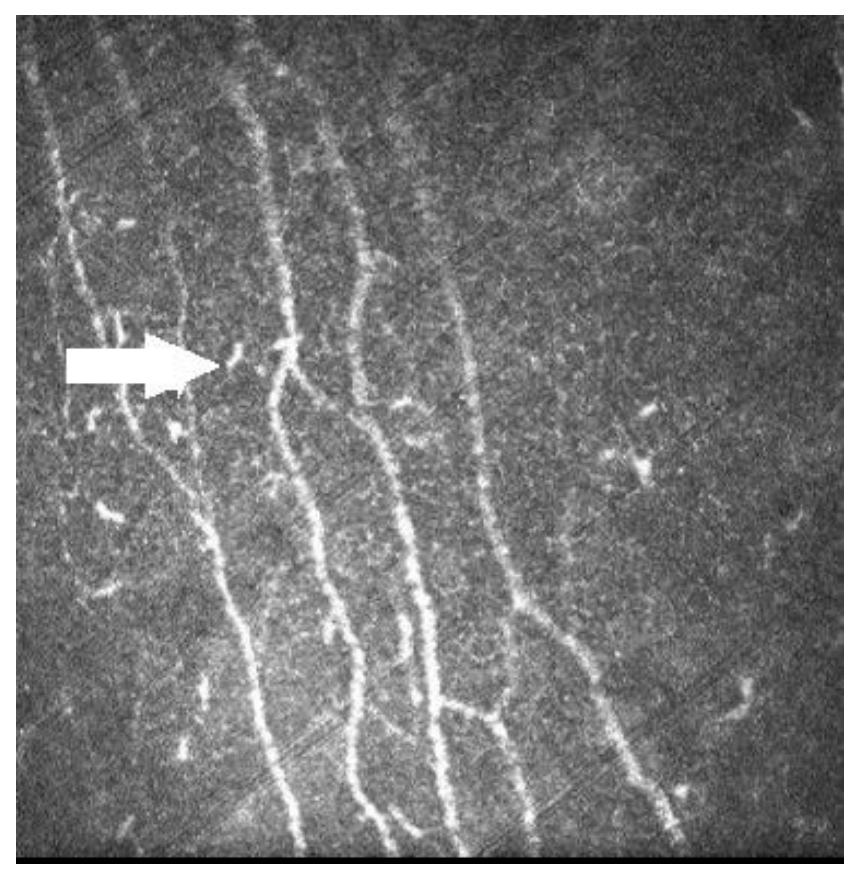

Figure 1. Confocal microscopic image of corneal LCs (arrow) in TAO patients. 
Langerhans cells were calculated by choosing the clearest picture from every layer of the epithelium that included the most apparent cells. The number of cells in the whole $400 \times 400 \mu \mathrm{m}^{2}$ image area was counted by using Java-based image processing and analysis freeware Image $(\mathrm{NIH}$, Bethesda, MD, USA) plus Counter Cell plugin and recorded as cells per square millimeter.

\section{Statistical Analysis}

All statistical analyses were performed using IBM SPSS for Windows version 20.0 (SPSS, Chicago, IL, USA). To determine the assumption of normality, the KolmogorovSmirnov test was used. Continuous variables were presented as mean \pm standard deviation or median (25th-75th percentile). Independent samples t-test/Mann-Whitney U test was used to compare continuous variables between groups, whichever was suitable. Associations between continuous variables were determined by Pearson and Spearman correlation analyses. The Chi-square test was used to examine the associations between two categorical variables. The significance was tested at the 5\% level and differences were considered statistically significant at $p \leq 0.05$.

\section{Results}

The demographic details and clinical characteristics of the TAO and control groups are presented in Table 1. Age and gender were not significantly different between the TAO patients and the control group. The mean clinical activity score was $1.55 \pm 1.25$ for TAO patients representing the inactive phase of GO. The mean BUT was 9.61 \pm 5.01 seconds in the TAO group and $12.70 \pm 2.76$ seconds in the control group $(p=0.003)$. The median central corneal LC density in the control group was 19.00 (7.00-24.50) whereas it was significantly increased to $68.00(50.00-92.00)$ in the TAO patients $(p<0.001)$.

Table 1. Demographic and clinical features of TAO patients and controls.

\begin{tabular}{|c|c|c|c|}
\hline & TAO $(n=33)$ & Control $(n=30)$ & $p$ \\
\hline $\begin{array}{l}\text { Gender } \\
\text { (Male/Female) }\end{array}$ & $15 / 18$ & $14 / 16$ & $1.000^{*}$ \\
\hline Age (years) & $43.67 \pm 2.43$ & $42.30 \pm 2.27$ & $0.639^{* *}$ \\
\hline BUT (seconds) & $9.61 \pm 5.01$ & $12.70 \pm 2.76$ & $0.003^{* *}$ \\
\hline $\mathrm{LC}\left(\operatorname{cell} / \mathbf{m m}^{2}\right)$ & $68.0(50.0-92.00)$ & $19.00(7.00-24.50)$ & $<0.001^{* * *}$ \\
\hline
\end{tabular}

${ }^{*}$ Chi-square test, ${ }^{* *}$ Student $\mathrm{t}$ test, ${ }^{* * * *}$ Mann Whitney U test

In correlation analysis, there was a significant negative correlation between age and CAS of TAO patients $(r=-0.348, p=0.047)$, and the age of TAO patients was not correlated with BUT and LC count $(r=0.236, p=0.186$ and $r=-0.211, p=0.240$, respectively). BUT of TAO patients was negatively correlated with LC count and CAS ( $r=-0.495$, $p=0.003$ and $r=-0.644, p<0.001$, respectively) (Figure 2). The CAS of the patients was not correlated with the LC count of the patients $(r=0.261, p=0.143)$. In the control group, BUT, CAS and LC count were not correlated with each other.
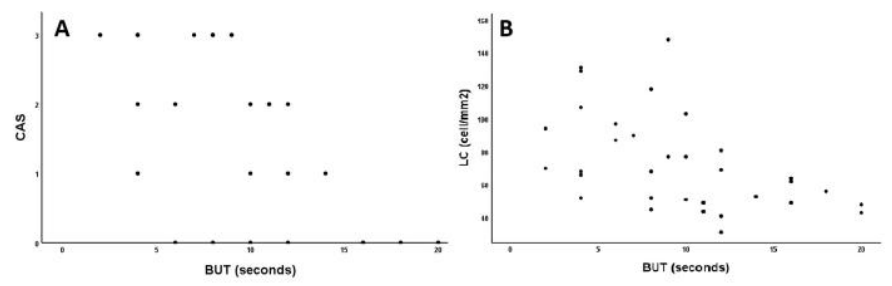

Figure 2. Correlations with the BUT. BUT of TAO patients correlated significantly with CAS (A) $(r=-0.644, p<0.001)$ and LC count $(\mathrm{B})(r=-0.495, p=0.003)$ of the patients with TAO.

\section{Discussion}

TAO can cause a variety of ocular surface problems related to the inflammatory process of the disease. In this study, we demonstrated increased LC density in the cornea of TAO patients in the inactive phase of the disease by using IVCM. Increased LC density was also associated with decreased BUT in the patient group. BUT was decreased in TAO patients and also decreased BUT was related to increased CAS showing more advanced disease.

In vivo confocal microscopy is a non-invasive technique for obtaining microscopic images of various cell populations from the ocular surface. Numerous researches have been reported about ocular surface changes in TAO using IVCM. Villani et al. discovered that the densities of corneal epithelial cells and stromal keratocytes in TAO patients were remarkably higher than controls. ${ }^{17}$ Also, they reported an increased density of activated keratocytes in patients with active TAO. Wei et al. reported higher LC density and lower goblet cell density in patients with TAO compared to the controls. ${ }^{18}$ A study reported by $\mathrm{Wu}$ et al. concluded that patients with TAO had increased density and maturation of LC. ${ }^{19}$

Corneal LCs have a role in the immunoregulation of the cornea. They regulate both innate and acquired immunity. They are normally found in the central cornea scarcely, but in extraordinary conditions, they transform into mature forms and migrate centrally. Also, in autoimmune conditions like TAO, it is expected to observe dry eye due to inflammation. In a study, both central and peripheral LC density was reported to increase in dry eye patients. ${ }^{20}$ In a study conducted in ankylosing spondylitis patients, Marsovszky et al. revealed that central and peripheral LC densities were correlated with the systemic activity of inflammatory disease even in the absence of ocular symptoms. $^{21}$ Also, in another Marsovszky et al. study, central LC density increased even in rheumatoid arthritis patients with remission. ${ }^{16}$ In our study, we evaluated inactive TAO patients and observed increased central LC density compared to controls in accordance with their results. Also, increased LC density was also associated with decreased BUT in the patient group. All these findings led us to think that this increase could be due to dry eye seen in TAO patients and/or continuing inflammation during the inactive phase of TAO.

Current study had some limitations. The first of these was the relatively small sample size. Second, we only examined the central cornea. Examining the peripheral cornea as in Wu et al. study could add further information to literature. ${ }^{19}$ In conclusion, TAO patients in the inactive phase suffer from ocular surface inflammation and LC participates in corneal inflammation of TAO. 


\section{Conflict of Interest}

The author has no conflicts of interest to disclose.

\section{Compliance with Ethical Statement}

The study numbered GOKAEK-2020/14.09 was approved by the Ethics Committee of KOU and followed the principles of the Declaration of Helsinki

\section{Financial Support}

The author declared that no financial support was received for this paper.

\section{Author Contributions}

BYT: Design, data collection, analysis, literature, manuscript writing, critical review

\section{References}

1. Kishazi E, Dor M, Eperon S, Oberic A, Hamedani M, Turck N. Thyroid-associated orbitopathy and tears: A proteomics study. $\quad J \quad$ Proteomics. 2018;170:110-116. doi:10.1016/j.jprot.2017.09.001

2. Ismailova DS, Fedorov AA, Grusha YO. Ocular surface changes in thyroid eye disease. Orbit. 2013;32(2):87-90. doi:10.3109/01676830.2013.764440

3. Selter JH, Gire AI, Sikder S. The relationship between Graves' ophthalmopathy and dry eye syndrome. Clin Ophthalmol. 2014;9:57-62. doi:10.2147/OPTH.S76583

4. Iskeleli G, Karakoc Y, Abdula A. Tear film osmolarity in patients with thyroid ophthalmopathy. Jpn J Ophthalmol. 2008;52(4):323-326. doi:10.1007/s10384-008-0545-7

5. Ujhelyi B, Gogolak P, Erdei A, Nagy V, Balazs E, Rajnavolgyi E et al. Graves' orbitopathy results in profound changes in tear composition: a study of plasminogen activator inhibitor-1 and seven cytokines. Thyroid. 2012;22(4):407-414. doi:10.1089/thy.2011.0248

6. Gürdal C, Saraç O, Genç I, Kırımlıoğlu H, Takmaz T, Can I. Ocular surface and dry eye in Graves' disease. Curr Eye Res. 2011;36(1):8-13. doi:10.3109/02713683.2010.526285

7. Rocha EM, Mantelli F, Nominato LF, Bonini S. Hormones and dry eye syndrome: an update on what we do and don't know. Curr Opin Ophthalmol. 2013;24(4):348-355. doi:10.1097/ICU.0b013e32836227bf

8. Abusharaha A, Alturki AA, Alanazi SA, Fagehi R, Al-Johani N, El-Hiti GA, Masmali AM. Assessment of tear-evaporation rate in thyroid-gland patients. Clin Ophthalmol. 2019;13:131135. doi:10.2147/OPTH.S188614

9. Choi EY, Kang HG, Lee CH, Yeo A, Noh HM, Gu N et al. Langerhans cells prevent subbasal nerve damage and upregulate neurotrophic factors in dry eye disease. PLoS One. 2017;12(4):e0176153. doi:10.1371/journal.pone.0176153

10. Hamrah P, Huq SO, Liu Y, Zhang Q, Dana MR. Corneal immunity is mediated by heterogeneous population of antigen-presenting cells. J Leukoc Biol. 2003;74(2):172-178. doi:10.1189/jlb.1102544

11. Lin H, Li W, Dong N, Chen W, Liu J, Chen L et al. Changes in corneal epithelial layer inflammatory cells in aqueous teardeficient dry eye. Invest Ophthalmol Vis Sci. 2010;51(1):122128. doi:10.1167/iovs.09-3629

12. Fiore T, Torroni G, Iaccheri B, Cerquaglia A, Lupidi M, Giansanti $\mathrm{F}$ et al. Confocal scanning laser microscopy in patients with postoperative endophthalmitis. Int Ophthalmol. 2019;39(5):1071-1079. doi:10.1007/s10792-018-0916-0

13. Mandathara PS, Stapleton FJ, Kokkinakis J, Willcox MDP. A pilot study on corneal Langerhans cells in keratoconus. Cont Lens Anterior Eye. 2018;41(2):219-223. doi:10.1016/j.clae.2017.10.005

14. Resch MD, Imre L, Tapaszto B, Nemeth J. Confocal microscopic evidence of increased Langerhans cell activity after corneal metal foreign body removal. Eur J Ophthalmol. 2008;18(5):703-707. doi:10.1177/112067210801800507
15. Bartalena L, Baldeschi L, Dickinson A, Eckstein A, KendallTaylor P, Marcocci C et al. Consensus statement of the European Group on Graves' orbitopathy (EUGOGO) on management of GO. Eur J Endocrinol. 2008;158(3):273-285. doi:10.1530/EJE-07-0666

16. Marsovszky L, Resch MD, Németh J, Toldi G, Medgyesi E, Kovács $\mathrm{L}$ et al. In vivo confocal microscopic evaluation of corneal Langerhans cell density, and distribution and evaluation of dry eye in rheumatoid arthritis. Innate Immun. 2013;19(4):348-354. doi:10.1177/1753425912461677

17. Villani E, Viola F, Sala R, Salvi M, Mapelli C, Currò N et al. Corneal involvement in Graves' orbitopathy: an in vivo confocal study. Invest Ophthalmol Vis Sci. 2010;51(9):45744578. doi:10.1167/iovs.10-5380

18. Wei YH, Chen WL, Hu FR, Liao SL. In vivo confocal microscopy of bulbar conjunctiva in patients with Graves' ophthalmopathy. J Formos Med Assoc. 2015;114(10):965972. doi:10.1016/j.jfma.2013.10.003

19. Wu LQ, Cheng JW, Cai JP, Le QH, Ma XY, Gao LD et al. Observation of Corneal Langerhans Cells by In Vivo Confocal Microscopy in Thyroid-Associated Ophthalmopathy. Curr Eye Res. 2016;41(7):927-932. doi:10.3109/02713683.2015.1133833

20. Lin H, Li W, Dong N, Chen W, Liu J, Chen L et al. Changes in corneal epithelial layer inflammatory cells in aqueous teardeficient dry eye. Invest Ophthalmol Vis Sci. 2010;51(1):122128. doi:10.1167/iovs.09-3629

21. Marsovszky L, Németh J, Resch MD, Toldi G, Legány N, Kovács L et al. Corneal Langerhans cell and dry eye examinations in ankylosing spondylitis. Innate Immun. 2014;20(5):471-477. doi:10.1177/1753425913498912 